\title{
Basaloid Carcinoma
}

National Cancer Institute

\section{Source}

National Cancer Institute. Basaloid Carcinoma. NCI Thesaurus. Code C4121.

A malignant epithelial neoplasm characterized by the presence of neoplastic cells with hyperchromatic nuclei, small amount of cytoplasm, and peripheral nuclear palisading. 